\title{
POTENTIAL OF INCOME INCREASE OBTAINED FROM VISITORS' PERCEPTION AND BEHAVIOUR TOWARDS SERULINGMAS WILDLIFE RECREATION PARK BANJARNEGARA
}

\author{
WIBIYANTO SETIAWAN $^{1 *}$, TUTUT SUNARMINTO ${ }^{2)}$, AND BURHANUDDIN MASY’UD ${ }^{2)}$ \\ 1) Tropical Biodiversity Conservation Study Program, IPB, IPB Campus Dramaga, Bogor, 16680, Indonesia \\ 2) Conservation of Forest and Ecotourism Department, Faculty of Forestry and Environment, IPB,
} IPB Campus Dramaga, Bogor, 16680, Indonesia

*Email: wibi.setiawan@gmail.com

Accepted October 07, 2020/Approved March 31, 2021

\begin{abstract}
The needs for a large amount of fund demand the conservation agency to be more creative and able to compromise the visitors`necessities as an effort to guarantee wildlife welfare by providing suitable environment and its infrastructure. The objective of this study is to obtain the data and information related to the potential of income increase gained from the visitors' perception and behavior towards Serulingmas Wildlife Recreation Park (TRM) in order to optimize many resources owned through tourism service innovations offered to visitors. The data were collected by delivering questionnaires to 150 visitors. The data collected included characteristics, motivations, and perceptions of visitors toward animal collection which were categorized into four, i.e.knowledge about animal, visitor behavior towards animals, collection rating, and animals`condition. Moreover, the condition of facilities in Serulingmas TRM was also evaluated. Furthermore, the management will be able to find the recent condition of collection animals based on the current information obtained from visitors. Thus, the information could be used to improve the management and increase the attractiveness about the animals for visitors. The results showed that seeing animals was the most popular activity for visitors and tiger was the favorite animal selected by the visitors of Serulingmas TRM. Visitors had a perception that the existence of Serulingmas TRM could increase knowledge and positive behaviors towards animals supported by a good and attractive cage arrangement, healthy animal condition, good facilities and service condition. Moreover, the visitor's interest in seeing animals along with the willingness of visitors to pay the entrance fee by adding the animal attraction could increase the income estimation by 36.67\% started from 2019 only if the management increased the entrance fee to Rp25,000.00 (based on visitors`Willingness to Pay value). The improvement of attraction that pays attention on the visitors`desire and needs by also considering animals`welfare can support a sustainable conservation agency.
\end{abstract}

Key words: ex situ conservation, Serulingmas Wildlife Recreation Park Banjarnegara visitors ` perception, willingness to pay

\section{INTRODUCTION}

Wildlife conservation can be performed both in the natural habitat (in situ) and outside the natural habitat (ex situ). One example of conservation performed in the outside the natural habitat is in the form of conservation agency. Regulation of the Minister of Environment and Forestry Number P.22/Menlhk/Setjen/Kum.1/5/2019 on conservation agency states that conservation agency is an institution engaging in the conservation of plants and/or wildlife outside their habitat (ex-situ), both in the form of government and non-government organizations. It has a main function to serve as a place for controlled breeding and/or preservation of plants and wildlife by still maintaining the purity of their kind. In addition to the main function, the conservation agency also plays a role as a place for education, demonstration, temporary care, brood-stock and genetic reserves to support in situ populations, healthy recreational facilities, as well as research and scientific development.

Serulingmas Wildlife Recreation Park (TRM) is one of conservation agency in Central Java that obtains a permission through the decree of the Minister of Environment and Forestry Number: 241/Kpts-II/1999 dated April 27 $7^{\text {th }}$ 1999. Serulingmas TRM is located in
Kutabanjar Urban Village, Banjarnegara Subdistrict, Banjarnegara Regency, Central Java Province. There are 47 species of animals with a total of 181 animals in Serulingmas TRM. When it was firstly established as a conservation agency, it was managed by the Regional Technical Implementation Unit (UPTD) under the Department of Tourism and Culture of Regional Government of Banjarnegara Regency.

In 2017, Serulingmas TRM management was changed into Regional Public Company (Perumda) through the Regional Regulation of Banjarnegara Regency Number 15 of 2017 on the Establishment of Regional Public Company of Serulingmas Wildlife Recreation Park. This change was intended to improve management professionalism and it was approved by the Regulation of the Minister of Forestry Number P.31/Menhut-II/2012 dated July $24^{\text {th }} 2012$ on conservation agency in article 21 stating that permission for conservation agency management for public interest is performed by State-Owned Enterprises (BUMN), Local-Owned Enterprises (BUMD), Private-Owned Enterprises, research institutes, formal educational institutions, corporations or foundations. When the management was changed from UPTD to Perumda, the fulfillment of all conservation agency operations must 
become the obligation of the management company, including the need of large fund reaching an average of 4 billion per year. Since Serulingmas TRM was managed by Regional Public Company, the number of visitor had increased from 231,863 visitors in 2018 to 272,261 visitors in 2019, and it also became one of superior tourisms in Banjarnegara Regency.

Efforts to achieve the objective of the conservation agency, which is to fulfill animal welfare requires a lot of funds because the natural needs of the animals must be fulfilled properly and maximally, such as the needs for foods, shelter (cage), sexuality and environment. The large need for funds demands the management to be creative and able to synergize the visitors' needs as one of efforts to fulfill the animal welfare through the provision of environment and supporting infrastructures (Davey 2006). The large fund can also be collected through independent efforts by utilizing the conservation agency function as a mean of recreation. Visitors are parties that can be developed by the conservation agency to obtain a source for management funds through the sales of recreational service. Kotler (2003) formulated services as activities or actions that can be offered by one party to another party which are basically intangible and do not result in any ownership in which its characteristics including intangibility, inseparability, diversity and perishability (not durable).

The research objective is to obtain data and information related to the potential of income increase obtained from visitor perception and behavior towards Serulingmas Wildlife Recreation Park in order to optimize the resources owned through tourism service innovations offered to visitors. Maximum receipt of funds is in line with the increasing number of visits by prioritizing animal welfare as the main factor, and synergizing with all relevant stakeholders for a sustainable conservation agency.

\section{RESEARCH METHOD}

This research was conducted in July to August 2020 and November 2020. Since the data collection process was constrained by COVID-19 pandemic, it was carried out in two stages. The research location was in Serulingmas TRM, Banjarnegara, Central Java. Data collection was performed through the distribution of questionnaires to 150 respondents based on $20 \%$ of average visitors per day representing various genders and age levels with classification of adolescents (13-19 yo), young adults (20-24 yo), adults (25-50 yo) and elderly (>50 yo). Moreover, the respondents were selected using convenience sampling technique. According to Neuman (2006), convenience sampling technique is performed by looking for visitors who are easily found and willing to be interviewed during the process of data collection, therefore the sampling can be easily performed. The scope of this research is to find the potential for Serulingmas TRM income through the service development based on the characteristic, motivation, and perception of the visitors on Serulingmas TRM. The visitors' data included four categories, which were the knowledge about animals, behavior towards the animals, collection rating and animals' condition in Serulingmas TRM, as well as the condition of service facilities there.

It was important to gain the visitors' perception in order to know the extent to which the condition of Serulingmas TRM met the visitors' expectation when they had a tour to enjoy the diversity and condition of the animals with the facility and service offered at Serulingmas TRM. The visitors' perception will provide an assessment through the impression, impact, and behavior towards the services provided by Serulingmas TRM manage that leads to the satisfaction level of visitors. If the knowledge and behavior of visitors are positive, then the satisfaction level of visitors is high and vice versa. So, the results of visitors' perception provide a support overview both material and non-material affecting the visitors' willingness to pay the tourism services offered by the Serulingmas TRM management.

The economic value potential data was found from the income estimation based on the willingness of visitors to pay for tourism services offered by the management through the average value of Willingness to Pay (WTP). Fauzi (2014) stated that the WTP value can describe the benefits of a proposed policy. In addition, Aryanto and Mardjuko (2005) emphasized that WTP is an assessment technique to quantify the concept of value for environmental services or natural resources. The value of the existence of natural resources is identified by the willingness of the part of community to pay for the preservation or use of recreational values. The visitor's willingness to pay (WTP) data for the tourism services provided by the management was obtained through a questionnaire distributed to 150 respondents.

According to Fauzi (2014), the elicitation technique can be used to bring up the WTP values by extracting the information on the ability to pay of the respondents by asking the payment amount through certain formats, one of which was bidding game method. This method was based on several "Yes" and "No" questions. And the last question was "what is the minimum or maximum amount of money that you will spend to pay?" This price was asked to respondents, if they agreed, then the price would be increased, and this question was continuously asked until the respondents answered "disagree" with the price. The potential of income increase was analyzed based on the average visitor's WTP to the tariff for animal attractions at the Serulingmas TRM and income estimation by applying ticket prices according to the visitor's WTP by referring to the number of visits in the previous year, which was 2019. The average WTP value was calculated using the following formula (Hanley and Splash 1993). 


$$
\mathrm{EWTP}=\frac{\sum_{\mathrm{i}=1}^{\mathrm{n}} \mathrm{Wi}_{\mathrm{i}}}{\mathrm{n}}
$$

Description :

EWTP : average WTP

Wi : WTP value of the respondent-i

$\mathrm{n} \quad$ : number of respondents

i : respondent-i who is willing to pay the ticket tariff to enjoy the attraction in Serulingmas $\operatorname{TRM}(\mathrm{i}=1,2, \ldots ., \mathrm{n})$

To find out the distribution of the average WTP value, the standard deviation calculation used was as follows:

$$
\mathrm{s}=\sqrt{\frac{1}{\mathrm{~N}-1}} \sum_{\mathrm{i}=1}^{\mathrm{N}}\left(\mathrm{x}_{1}-\overline{\mathrm{x}}\right)^{2}
$$

Description:

$$
\begin{array}{ll}
\mathrm{s} & : \text { standard deviation } \\
\mathrm{N} & : \text { total data } \\
\mathrm{i} & : \text { data number }(\mathrm{i}=1,2,3 \ldots \mathrm{N}) \\
\mathrm{x}_{1} & : \text { data of respondent- }(\mathrm{i}=1,2,3 \ldots \mathrm{N}) \\
\mathrm{X} & : \text { average sample }
\end{array}
$$

Data for visitors' perception are obtained from closed questionnaires using Likert Scale 1-5 (Table 1). The data were processed using the average score technique to measure the weight of respondents' perception (Martin 2007). The interval score must be determined first before determining the score for each respondent. Based on the number of respondents, which were 150 respondents, the lowest average score was 1 and the highest average score was 5 , so the score interval for each group was 0.8. Based on the score interval, the interval for the assessment of each criterion was obtained and it was categorized as strongly disagree (STS: 1.001.80), disagree (TS: 1.81-2.60), somewhat agree (CS: 2.61-3.40), agree (S: 3.41-4.20), strongly agree (SS: 4.21-5.00).

Table 1 Answer Score using Likert Scale.

\begin{tabular}{lc}
\hline Likert Scale & Score \\
\hline Strongly Agree (SA) & 5 \\
Agree (A) & 4 \\
Somewhat Agree (SWA) & 3 \\
Disagree (D) & 2 \\
Strongly Disagree (SD) & 1 \\
\hline
\end{tabular}

Source: Joshi et al. (2015)

\section{RESULT AND DISCUSSION}

\section{Characteristics of Serulingmas TRM Respondents}

The researchers expected to obtain reliable data and information from the questionnaires, so the research subjects selected were Serulingmas TRM visitors with age above 13 years old categorized as adolescents. There were $44.67 \%$ male visitors and $55.33 \%$ of female visitors selected to be the respondents. Most of visitors came from Banjarnegara, they visited Serulingmas TRM alone or in a group (Figure 1). We could see that most of visitors came to Serulingmas TRM with their families $(56 \%)$ and some with their friends (16\%), thus it could be concluded that Serulingmas TRM was one of the recreational and entertainment destinations to spend time with family and friends. This result was consistent with the results of a research at Edinburgh Zoo according to Karanikola et al. (2014), that the main motivation and reasons for visiting the zoo were due to the desire to be able to go with friends and relatives (36\%), to obtain entertainment (27\%), for recreation (12\%), to see rare and exotic animal species (5\%), and for visits to gain knowledge about animals (4\%).

The educational background of the respondents consisted of high school $42 \%$, junior high school $23 \%$, college $22 \%$, elementary school $11 \%$, and others $3 \%$. The education level of visitors at the secondary and higher education levels showed the characteristics of visitors as the basis for developing insight and knowledge, especially related to animal conservation, for example through research activities and educational tours. Nekolny and Fialova (2018) stated that a zoo is a special cultural and educational facility that has four main tasks, namely: conservation of endangered species, science and research, education, and human recreation. Collins et al. (2019) added that currently intervention in the world of education is an effort to reduce negative behavior of visitors and improve animal welfare positively.

\section{Motivation of Serulingmas TRM Visitors}

Spenceley et al. (2015) stated that visitors' experience will make contribution to support the management's objective and related to the experience during the visit, if the visitors gain positive experience then they will spread the positive recommendation of the place and vice versa. The visitors' satisfaction is expected to be effective means for promoting to other potential visitors, especially regarding the animal collection. Information obtained by visitors and promotion offered by the management became the basis for visitors to make visit. Visitors obtained information about Serulingmas TRM from social media (38\%), families $(30 \%)$, friends $(18 \%)$, brochures $(15 \%)$, television $(3 \%)$, newspaper $(2 \%)$, and magazine $(1 \%)$. Spenceley et al. (2015) stated that visitors built up expectation long before making tourism visit based on information they obtained via websites, social media, promotional materials, and from words of mouth. The result of the samples of respondents showed that $89 \%$ of visitors had visited Serulingmas TRM before and $11 \%$ of visitors admitted that it was their first time to visit Serulingmas TRM. Therefore, it indicated that the visitors obtained satisfaction in visiting Serulingmas TRM. The intensity of visits was more than three times and even dominated as much as $67 \%$ (Figure 2). 


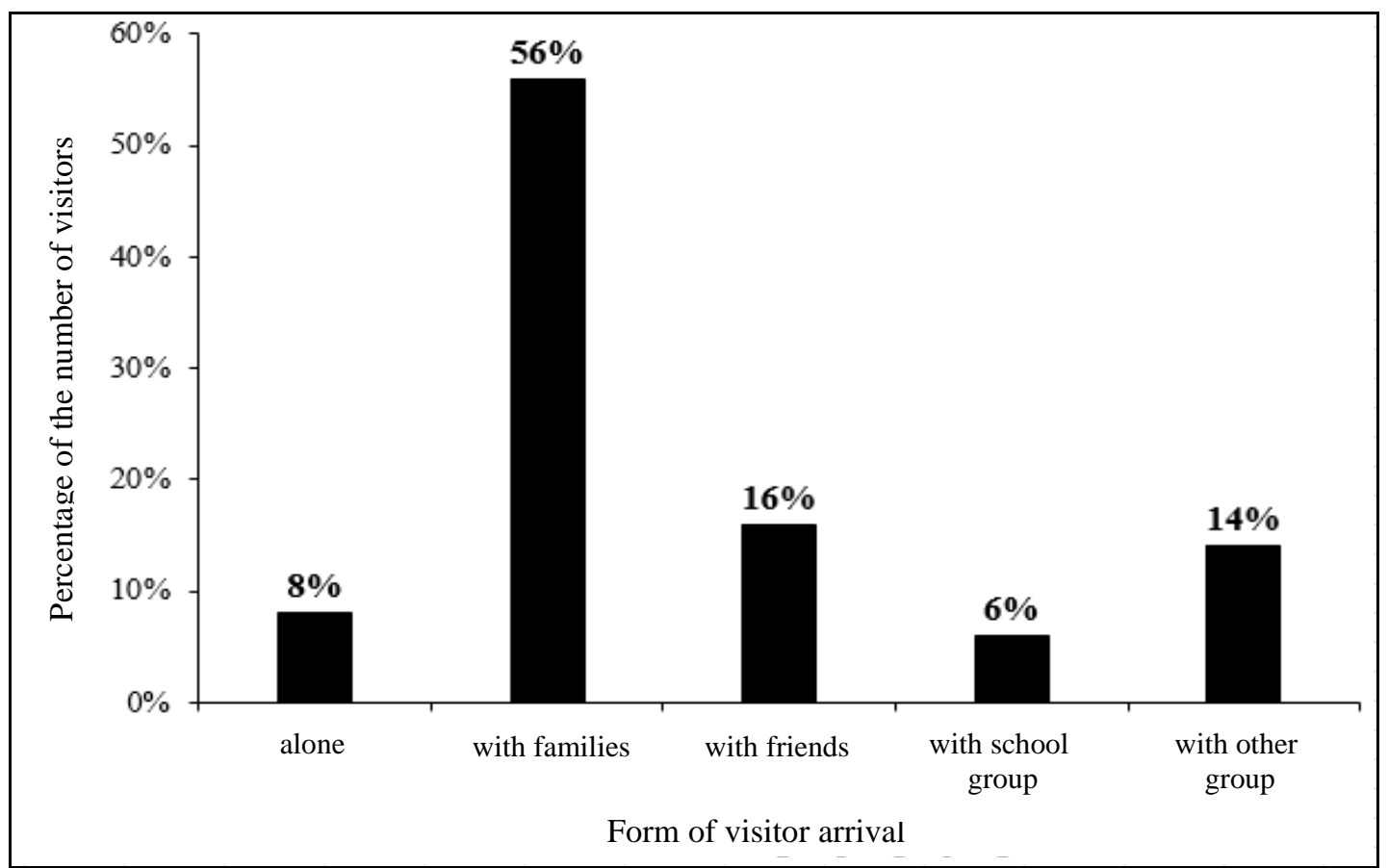

Figure 1 Form of arrival of visitors to TRM Serulingmas

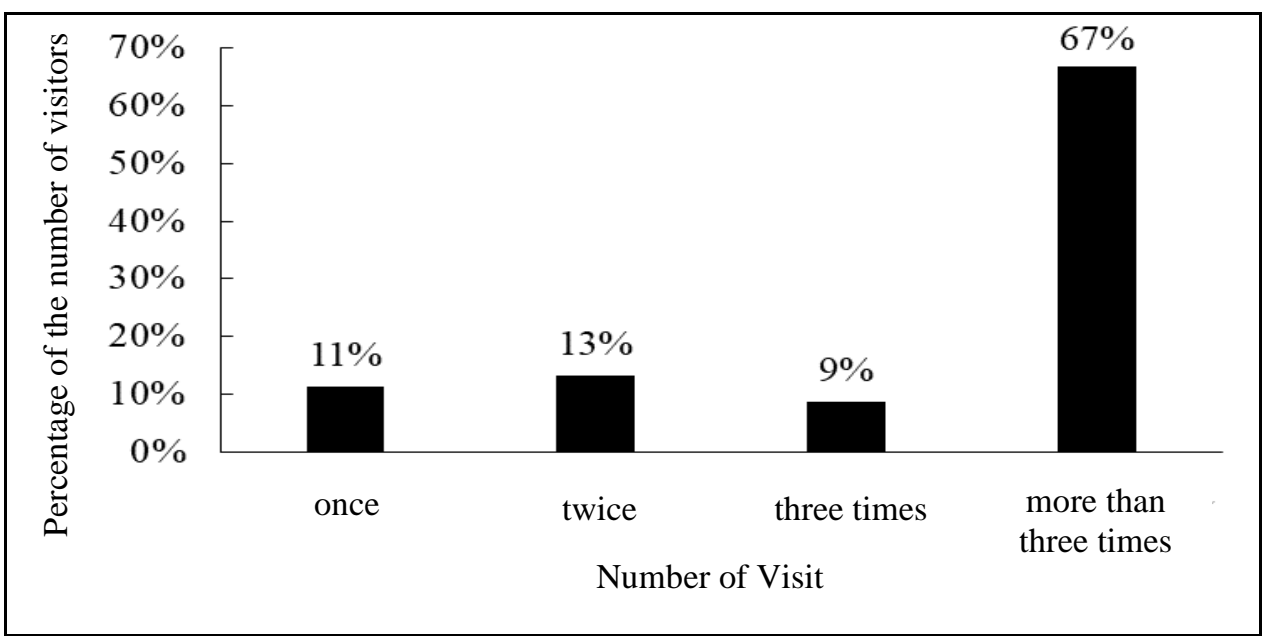

Figure 2. Number of visit of Serulingmas TRM visitors

Conservation agency, as one of the ex-situ conservation efforts, showed that the presence of animals was the key to support tourism functions. Curiosity and love for animals attracted visitors to see, feed and even take pictures. This was reflected in the percentage of activities that most visitors preferred to do in Serulingmas TRM, such as seeing the animals and taking pictures (Figure 3).

\section{Perceptions of Serulingmas TRM Visitors}

Based on the results of scoring the perceptions and behaviors of visitors, it was found that that Serulingmas TRM visitors had good perceptions and behaviors in supporting the ex situ animal conservation management efforts carried out by the TRM Serulingmas conservation agency. Overall, the value obtained from the perception parameter (Figure 4) was in average of 3.81. Visitors who gave responses tended to agree that the Serulingmas TRM animal collection was diverse and showed no signs of illness. Placing animals in cages that were clean, maintained, and looked like in their natural habitat also allowed the visitors to see the animal clearly. Visitors were also asked to show their agreement or disagreement with a series of statements relating to the facilities available at TRM Serulingmas. As a result, visitors agreed that the Serulingmas TRM management provided facilities supporting comfort while traveling, such as cleanliness and well-organized garden conditions, information boards for visitors, and good officer service. 


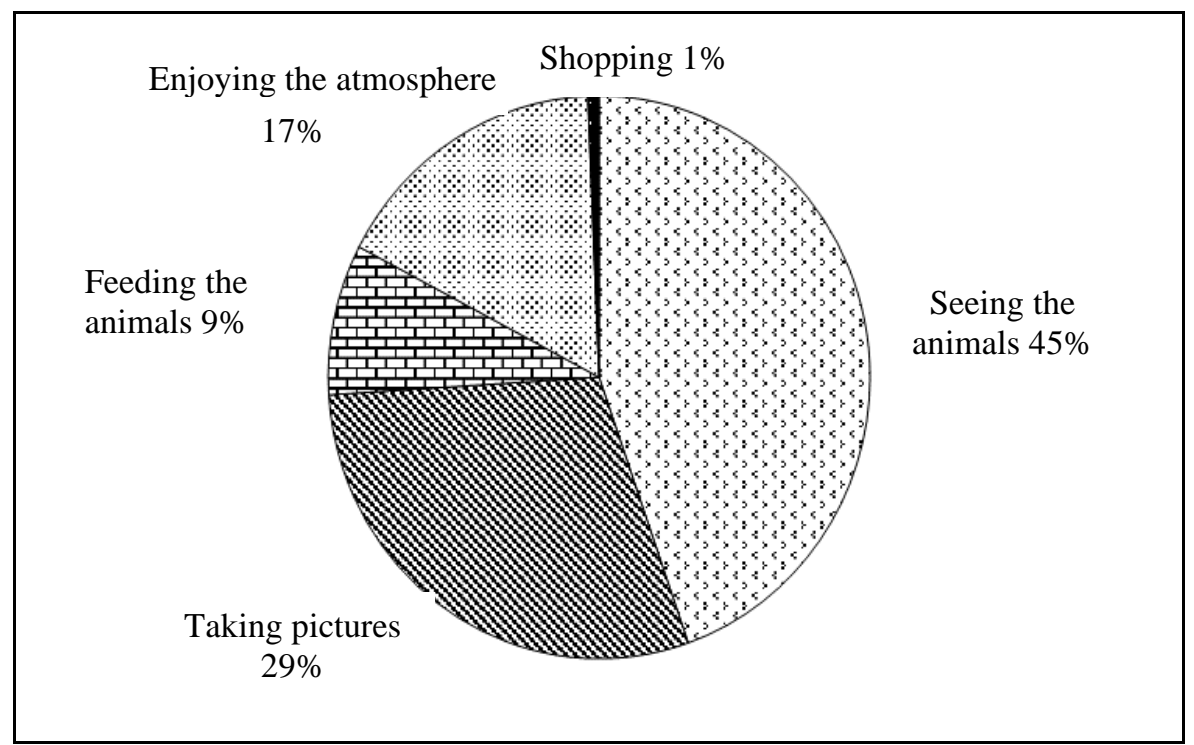

Figure 3. Activities Preferred by Serulingmas TRM visitors

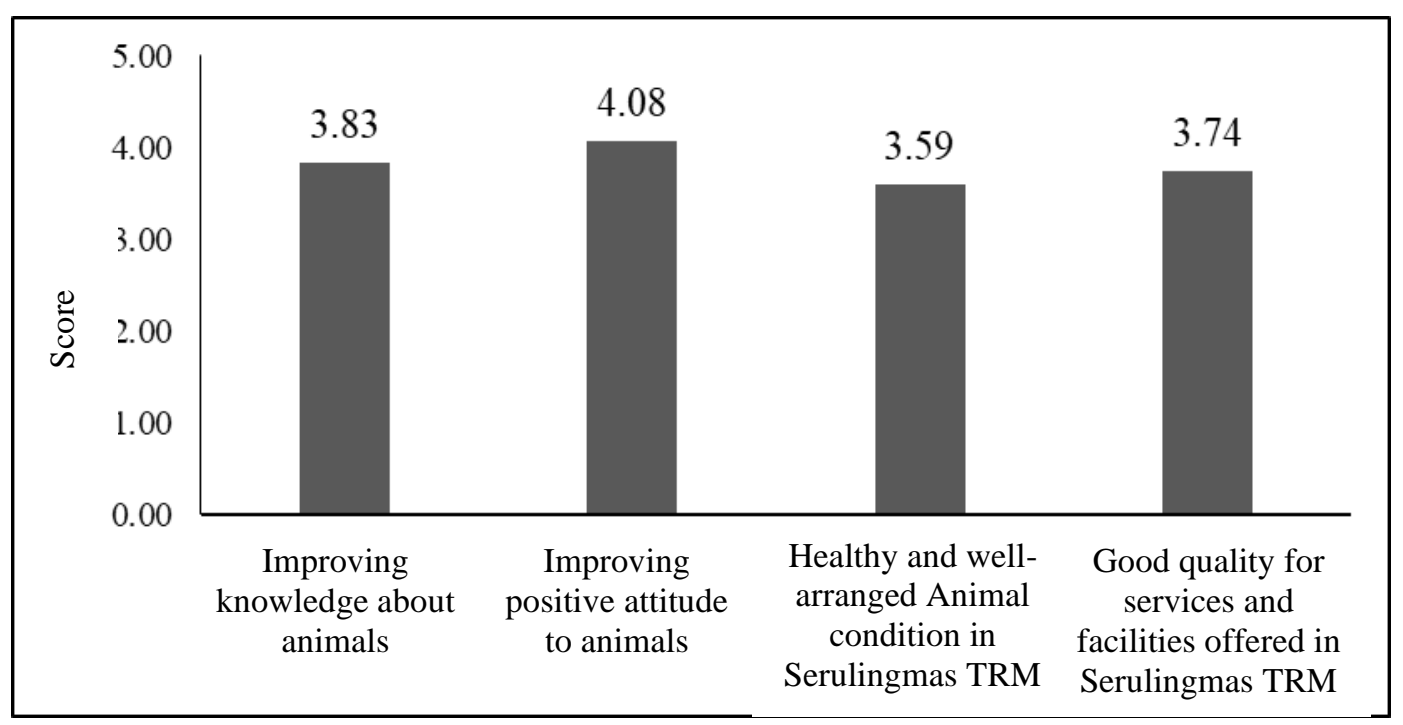

Figure 4. The results of scoring the perceptions and behaviors of TRM Serulingmas visitors

The visitors agreed that the presence of Serulingmas TRM conservation agency provided additional insights and understanding related to the management of animal welfare and agreed with positive behavior shown by society in supporting conservation efforts through activities to rescue wild animals, especially those endangered and protected by law, for example, by not hurting animals and not killing animals. It is important to have understanding about human activities that may affect animals' responses because it is one of factors capable of improving animal welfare and its productivity (Hemsworth and Gonyou 1997). With perception, a behavior that tends to be stable to act or react in certain way and in certain situation also can be formed. In addition, it is necessary to develop management of conservation agency based on visitor interpretation-based approach, an approach involving more diverse visitor behavior and impacts on the environment during the visit and after the visit (Ballantyne et al. 2018).

\section{Potential of Income Increase}

Based on the research results, the most favorite animal obtaining visitors' attention was tiger and then it was followed by birds, orangutan, deer and crocodile (Figure 5). This information can be used as a basis for developing tourism programs to increase attractiveness as well as greater attention from the management on visitors' favorite animals, especially in providing treatment because they are the most valuable asset for the conservation agency of Serulingmas TRM. The visitors' perception tended to be in line with the opinion of Carr (2016) who stated that visitors are very interested in seeing mammals that are morphologically large in size. 
Today, the management of Serulingmas TRM charges a ticket price at Rp15,000.00 per person to enter and see the animals. $73 \%$ visitors considered the price as cheap, while $27 \%$ visitors considered it as expensive. Based on the information, the management has opportunity to increase the income from the visitors by increasing the entrance ticket price. This can be performed by utilizing the attractiveness of visitors' favorite animals, in which the management can develop a tourism service by organizing animal show that is in accordance with the Regulation of Minister of Environment and Forestry Number P.22/MENLHK/SETJEN/KUM.1/5/2019 on Conservation Agency in which one of conservation agency roles is organizing a show.

An animal show that is attractively packaged can provide conservation education to visitors while still paying attention to animal welfare and it becomes unique and different attraction for visitors. Hosey (2000) stated that each animal appearing in the show has its own uniqueness, both due to morphology and the character of the sound, which will become an attraction so as to encourage interaction between visitors and animals. The interaction between visitors and animals will increase visitors' interest in a zoo. If visitors feel interested, they will be willing to spend money to be able to enjoy the animal show presented by the management.

Bidding game method given to respondents resulted in a fact that $91.3 \%$ of respondents had willingness to pay (WTP) higher than the entrance ticket price today if the management of Serulingmas TRM organized animal show/attraction, but $8.7 \%$ respondent did not have willingness to pay (WTP). According to the total respondents who were willing to pay higher ticket price than applicable ticket price today, the WTP value obtained was started from Rp20,000.00 to Rp70,000.00 (Figure 6).

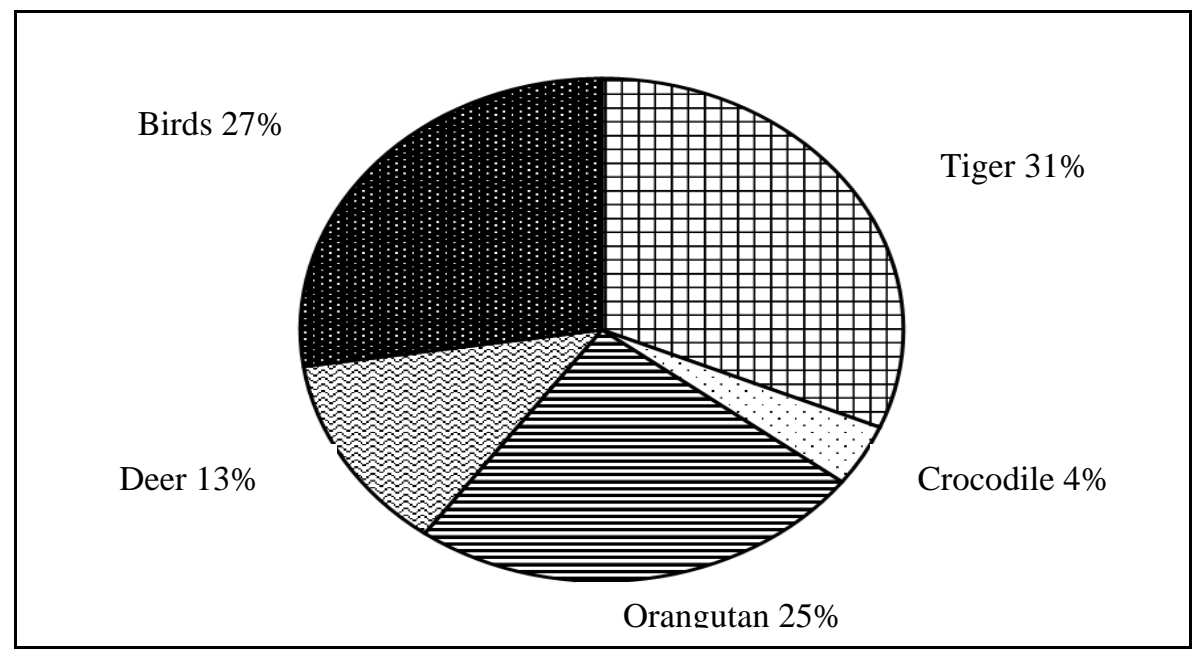

Figure 5. Favorite Animal Species of Serulingmas TRM Visitors

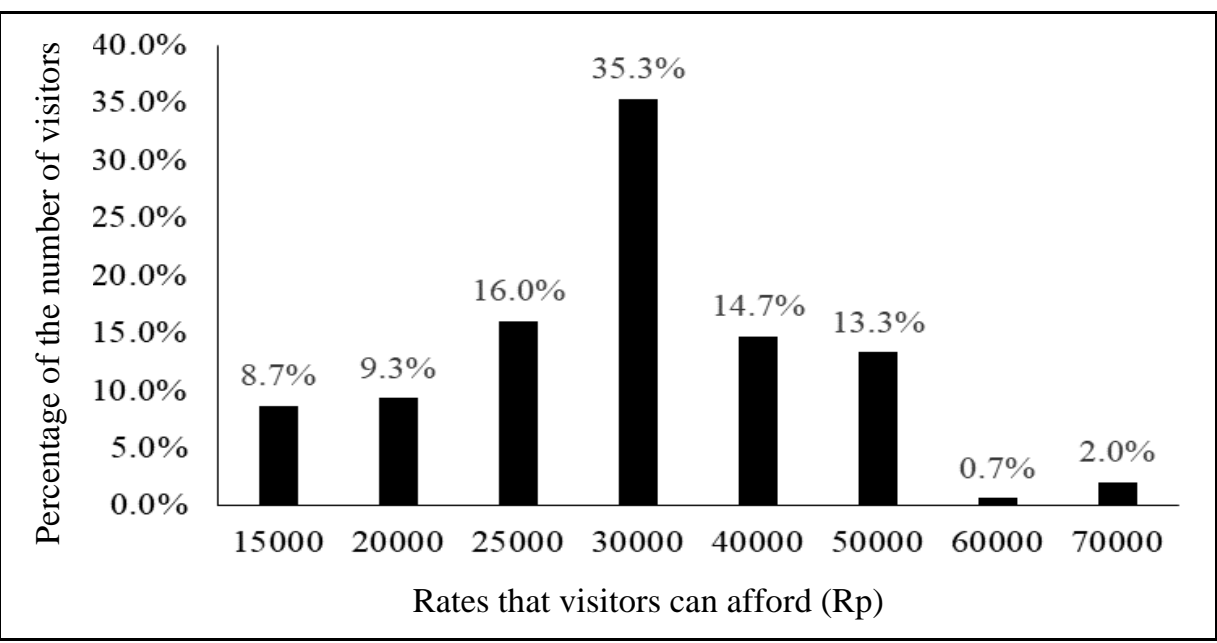

Figure 6. Rates that the Serulingmas TRM visitors can afford 
The final result of the calculation shows that the average WTP of visitors is Rp32,100.00 with a standard deviation of 3,499.294 (Table 2). The standard deviation value means that the average data is spread with a value of Rp3,499.294 or equivalent to Rp3,500.00 (rounded) per ticket price per person. Of the 150 visitor respondents, there were $104(69.33 \%)$ respondents who were not willing to pay more than the average WTP value of the visitor. If the ticket rate is set according to the average WTP of visitors, it will result in a decrease in the number of visitors.
Table 3 shows that the change in ticket prices from $\mathrm{Rp} 15,000.00$ to $\mathrm{Rp} 25,000.00$ per person is estimated to provide the highest income of Rp5,581,350,500.00 per year assuming the number of visitors is the same as in 2019. A higher WTP value for visitors was based on the expectation of improvement in the tourist attractions presented at TRM Serulingmas by presenting more diverse tourist attraction, especially in presenting entertaining tourist attractions involving large mammals and various birds. Visitors were mostly families bringing children having a great interest in a variety of the animals.

Table 2. Average willingness to pay (WTP) of respondents for the entrance ticket price in Serulingmas TRM with the addition of animal attractions, August 2020.

\begin{tabular}{ccc}
\hline $\begin{array}{c}\text { WTP values } \\
\text { Rp/ticket/person }\end{array}$ & Visitor & Income \\
Frequency (person) & $\mathrm{c}=\mathrm{a} \times \mathrm{b}$ \\
\hline 15000 & $\mathrm{~B}$ & 195000 \\
20000 & 13 & 280000 \\
25000 & 14 & 600000 \\
30000 & 24 & 1590000 \\
40000 & 53 & 880000 \\
50000 & 22 & 1000000 \\
60000 & 20 & 60000 \\
70000 & 1 & 210000 \\
\hline Total & 3 & 4815000 \\
\hline Average WTP & 150 & Rp32,100.00/ticket/person \\
\hline
\end{tabular}

Table 3 Income estimation of Serulingmas TRM per year with the application of ticket prices according to the visitor's WTP

\begin{tabular}{|c|c|c|c|c|}
\hline \multirow[b]{2}{*}{$\begin{array}{c}\text { RP/ticket/person } \\
\mathrm{a} \\
\end{array}$} & \multicolumn{2}{|c|}{ Visitors } & \multirow{2}{*}{$\begin{array}{l}\text { Income Estimation } \\
\begin{array}{c}(\mathrm{Rp} / \mathrm{yr}) \\
\mathrm{d}=\mathrm{a} \times \mathrm{c}\end{array} \\
\end{array}$} & \multirow{2}{*}{$\begin{array}{c}\text { Estimated Increase (decrease) in income } \\
\% \\
\mathrm{E} \\
\end{array}$} \\
\hline & $\begin{array}{l}\% \\
\mathrm{~b}\end{array}$ & $\begin{array}{c}\text { Person } \\
\mathrm{c}=\mathrm{b} \times \mathrm{N} \\
\end{array}$ & & \\
\hline $32,100.00$ & 30.61 & 83,493 & $2,680,137,284.00$ & $(34.37)$ \\
\hline $30,000.00$ & 66.00 & 179,692 & $5,390,767,800.00$ & 32.00 \\
\hline $25,000.00$ & 82.00 & 223,254 & $5,581,350,500.00$ & 36.67 \\
\hline $20,000.00$ & 91.33 & 248,665 & $4,973,300,933.33$ & 21.78 \\
\hline $15.000,00$ & 100.00 & 272,261 & $4,083,915,000.00$ & 0 \\
\hline
\end{tabular}

\section{CONCLUSION}

Income increase estimation in Serulingmas Wildlife Recreation Park (TRM) using the willingness to pay approach method was $36.67 \%$ or an increase of Rp1,497,435,000.00 with a change in the entrance tickets price from $\mathrm{Rp} 15,000.00$ to $\mathrm{Rp} 25,000.00$ per person. The potential of increased income was driven by the motivation and good perception of visitors in supporting efforts to develop ex-situ conservation at Serulingmas TRM. This was reflected through the people enthusiasm, in which around $76 \%$ of visitors had come to Serulingmas TRM three times and more. As a result, Serulingmas TRM became a favorite family tourist destination. The higher WTP value of visitors can be realized by the management by increasing the variety of 
attractive animal attractions, especially large mammals and birds while still paying attention to animal welfare so as to support the creation of a sustainable conservation agency.

\section{REFERENCES}

Aryanto R, Mardjuka MY. 2005. Valuasi ekonomi dengan travel cost method pada objek ekowisata pesisir (Kasus Kawasan Ujung Genteng, Sukabumi). Jurnal Ilmiah Pariwisata. 10 (1): 5876.

Ballantyne R, Hughes K. Lee J, Packer J, Sneddon J. 2018. Visitors' values and environmental learning outcomes at wildlife attractions: Implications for interpretive practice. Tourism Management. 64: 190-201.

Carr N. 2016. Ideal animals and animal traits for zoos: General public perspectives. Tourism Management. 57:37-44. http://dx.doi.org/10.1016/j.tourman. 2016. 05.013.

Collins C, Quirke T, McKeown S, Flannery K, Kennedy D, Riordana RO. 2019. Zoological education: Can it change behaviour?. Applied Animal Behaviour Science. 220: 1-10.

Davey G. 2006. Relationships between exhibit naturalism,animal visibility andvisitor interestin a Chinese Zoo. Applied Animal Behaviour Science. 96: 93-102.

Fauzi A. 2014. Valuasi Ekonomi dan Penilaian Kerusakan Sumber Daya Alam dan Lingkungan. Bogor: IPB Pr.
Hanley N, Splash CL. 1993. Cost Benefit Analysis and The Environment. England: Edward Elgar Publishing Limited

Hemsworth PH, Gonyou HW. 1997. Animal Welfare: Human Contact. Aplleby MC, Hughes BO, editor. Wallingford: CAB International.

Hosey GR. 2000. Zoo animals and their human audiences: What is the visitor effect? Animal Welfare. 9 (4): 343-357.

Joshi A, Kale S, Chandel S, Pal DK. 2015. Likert scale: explored and explained. British Journal of Applied Science \& Technology. 7 (4): 396-403

Karanikola P, Tampakis S, Tsantopoulos G, Digbasani C. 2014. The public zoo as recreation and environmental education area: Visitor's perceptions and management implications. WSEAS Transactions on Environment and Development. 10: 81-91

Kotler P. 2003. Marketing Management. Elevent Edition. New Jersey: Pearson Education, Inc.

Martin P. 2007. Analisis pengaruh kompensasi terhadap motivasi kerja pada CV Aquatic Indonesia. [tesis]. Bogor: Institut Pertanian Bogor.

Nekolny L, Fialova D. 2018. Zoo Tourism: What Actually Is a Zoo? Czech Journal of Tourism. 7 (2) : 153-166. DOI: $10.1515 /$ cjot-2018-0008.

Neuman ML. 2006. Social research methods: qualitative and quantitative approaches. Boston: Pearson.

Spenceley A, Kohl J, McArthur S, Myles P, Notarianni M, Paleczny D, Pickering C, Worboys GL. 2015. Visitor management. Canberra (AU): ANU Press. 